\title{
Determinan Yang Mempengaruhi Jumlah Permintaan Kredit Pemilikan Rumah di Indonesia
}

\author{
Rifki Khoirudin \\ Fakultas Ekonomi \& Bisnis Universitas Ahmad Dahlan \\ Jl. Kapas No. 9, Semaki, Umbulharjo, Yogyakarta \\ email : rifki.khoirudin@ep.uad.ac.id
}

\begin{abstract}
ABSTRAK
Penyaluran kredit perbankan pada sektor konsumsi mengalami peningkatan yang drastis sejak Indonesia dilanda krisis ekonomi sepuluh tahun lalu. Hal ini terjadi karena banyaknya perusahaanperusahaan besar bangkrut sehingga sektor korporasi sangat sedikit menyerap kredit dari bank. Bank-bank kemudian semakin menyadari bahwa peluang di pasar konsumsi semakin besar, dimana resiko yang dihadapi relatif lebih kecil dibandingkan dengan kredit pada pasar investasi. Dengan mengasumsikan bahwa rumah sebagai kebutuhan pokok yang tidak memiliki barang pengganti, maka kemungkinan bagi seorang konsumen yang ingin memiliki rumah baik itu secara tunai maupun kredit hanyalah menyesuaikan jenis rumah yang sesuai dengan kemampuan dengan tingkat pendapatan yang berbeda-beda oleh setiap individu. Dalam penelitian ini, metode yang digunakan adalah regresi linear berganda. Dari variabel independen yakni pertumbuhan ekonomi, suku bunga kredit dan indeks harga properti residensial mampu mempengaruhi variabel dependen yakni kredit pemilikan rumah sebesar $97,9 \%$.
\end{abstract}

\section{Kata kunci : Kredit Pemilikan Rumah, Pertumbuhan Ekonomi, Suku Bunga.}




\title{
Determinants Affecting The Number of Demand For Mortgages in Indonesia
}

\begin{abstract}
Bank lending to the consumption sector has increased dramatically since Indonesia was hit by the economic crisis ten years ago. This happens because many large companies go bankrupt so that the corporate sector absorbs very little credit from banks. Banks are increasingly recognizing that opportunities in the consumer market are growing, where the risks they face are relatively smaller compared to those in the investment market. Assuming that the house is a basic necessity that does not have substitutes, the possibility for a consumer who wants to own a home either in cash or credit is simply adjusting the type of home that suits the ability with different income levels by each individual. In this research, the method used is multiple linear regression. From independent variable that is economic growth, loan interest rate and residential property price index able to influence dependent variable that is mortgage credit equal to 97,9\%.
\end{abstract}

Keywords: Home Ownership Credit, Economic Growth, Interest Rate.

\section{PENDAHULUAN}

\section{Latar Belakang Masalah}

Rumah adalah suatu barang yang khas dengan karakteristik unik diantara semua barang lain yang digunakan secara umum. Hakikat perumahan atau kediaman tidak hanya mencakup rumah dari sisi fisik bangunan, melainkan meliputi segala kelengkapan fasilitas pendukungnya baik yang ada dari dalam ataupun dari luar. Dalam arti khusus, rumah mengacu pada konsep-konsep sosial-kemasyarakatan yang terjalin di dalam bangunan tempat tinggal, seperti keluarga, hidup, makan, tidur, beraktivitas, dan lain-lain (Wikipedia, 2013). Lebih lagi bila dilihat dukungan fasilitas dan aksesbilitas yang ada, sebagai contoh sistem keamanan lingkungan, sistem saluran air limbah, sarana jalan, jaringan listrik, jaringan telpon dan lain sebagainya (Komarudin, 1997).

Real estate adalah semua benda yang termasuk di dalam dan di atas tanah yang merupakan bagian alam dari tanah dan juga semua benda yang dibuat dan dibangun oleh manusia (misalnya : bangunan rumah, sumur dan jaringan pipa air bersih) (AIREA, 2001). Elemen yang membentuk pasar perumahan dan perilaku para pelaku pasar menurut AIREA (2001) adalah : 
Published Desember 2017

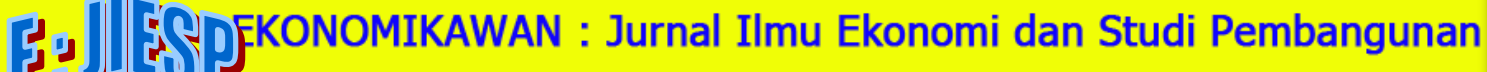

נע נISSN : 1693-7600 (Print), ISSN : 2598-0157 (Online), http://jurnal.umsu.ac.id/index.php/ekawan

1. Lokasi, terkait erat dengan wilayah mana keputusan ekonomi yang relevan dilakukan.

2. Kompetisi, berhubungan dengan fungsi permintaan dan penawaran, ketersediaan rumah dan jumlah pembeli potensial pada pasar.

3. Permintaan unit merupakan suatu bagian yang menyatakan permintaan atas suatu produk yang didasarkan pada demografi, yang mendefinisikan jumlah pembeli sekarang dan yang akan datang.

Masyarakat memiliki beberapa pilihan dalam memiliki rumah, seperti membangun sendiri atau sewa, membeli secara tunai atau angsuran, maupun dengan cara lain. Pembelian secara tunai dilakukan apabila pembeli memiliki sejumlah uang yang nilainya sama dengan harga rumah. Namun, tidak setiap orang mampu membeli rumah secara tunai. Untuk memenuhi kebutuhan akan perumahan, pemerintah menyediakan dan menyelenggarakan program yang ditujukan untuk tercapainya tujuan tersebut melalui program kredit perumahan bagi masyarakat. Program kredit tersebut dilaksanakan sesuai amanat Undang-Undang Nomor 1 tahun 2011 Pasal 43 Ayat 2 tentang Perumahan dan Kawasan Permukiman bahwa pemilikan rumah dapat difasilitasi dengan kredit atau pembiayaan pemilikan rumah.

Kebutuhan rumah di Indonesia setiap tahunnya terus bertambah. Berdasarkan hitungan Real Estate Indonesia (REI), total kebutuhan rumah per tahun di Indonesia bisa mencapai 2,6 juta yang didorong oleh pertumbuhan penduduk. Berdasarkan data jumlah penduduk sekarang ini lebih kurang 241 juta jiwa dengan angka pertumbuhan penduduk $1,3 \%$ per tahun dapat dipastikan kebutuhan terhadap perumahan akan meningkat. Melihat besarnya angka kebutuhan rumah maka harus diperlukan penyediaan dana yang besar untuk membangunnya. Pembelian rumah bisa dilakukan dengan cara tunai ataupun kredit. Seseorang dapat membeli rumah secara tunai apabila orang tersebut memiliki uang yang nilainya sama dengan harga rumah tersebut. Namun seiring dengan semakin sulitnya keadaan ekonomi dan banyaknya tuntutan kebutuhan yang harus dipenuhi oleh masyarakat maka pembelian rumah secara tunai akan semakin sulit dilakukan, terutama bagi kalangan masyarakat yang menengah ke bawah. Dengan demikian, pembelian rumah secara kredit dikalangan masyarakat pada umunya menjadi pilihan yang sangat menarik.

Penyaluran kredit perbankan pada sektor konsumsi mengalami peningkatan yang drastis sejak Indonesia dilanda krisis ekonomi sepuluh tahun lalu. Hal ini terjadi karena banyaknya perusahaan-perusahaan besar bangkrut sehingga sektor korporasi sangat sedikit menyerap kredit dari bank. Bank-bank kemudian semakin menyadari bahwa peluang di pasar konsumsi semakin besar, dimana resiko yang dihadapi relatif lebih kecil dibandingkan dengan kredit pada pasar investasi. Terdapat beberapa jenis sektor konsumsi yang dibiayai dengan kredit oleh bank, salah satunya adalah sektor perumahan melalui kredit pemilikan rumah (KPR). Peningkatan pemberian KPR oleh bank-bank disebabkan masih banyaknya masyarakat yang membutuhkan rumah. Pada sisi lain, sebagian masyarakat tidak mampu membeli rumah secara tunai, sehingga ini menjadi peluang bagi bank-bank untuk memasarkan KPR sebanyak-banyaknya.

Pada dasarnya keputusan seseorang untuk memiliki rumah dipengaruhi oleh motif konsumsi dan motif investasi. Dengan mengasumsikan bahwa rumah sebagai kebutuhan pokok yang tidak memiliki barang pengganti, maka kemungkinan bagi seorang konsumen yang ingin memiliki rumah baik itu secara tunai maupun kredit hanyalah menyesuaikan jenis rumah yang sesuai dengan kemampuan dengan tingkat pendapatan yang berbedabeda oleh setiap individu. 


\section{Rumusan Masalah}

Banyaknya faktor yang mempengaruhi keputusan pemilihan rumah di balik naik turunnya akan permintaan rumah, seperti dijelaskan Karsidi (2002) bahwa faktor penyebab dari permasalahan adalah faktor sisi permintaan. Adanya permintaan untuk memiliki rumah dibatasi oleh tingkat penghasilan serta biaya membangun rumah. Atas dasar uraian tersebut permasalahan dalam penelitian ini dirumuskan sebagai berikut :

1. Bagaimana pengaruh Pertumbuhan Ekonomi terhadap permintaan Kredit Kepemilikan Rumah (KPR)

2. Bagaimana pengaruh Suku Bunga Kredit terhadap permintaan Kredit Kepemilikan Rumah (KPR)

3. Bagaimana pengaruh Indeks Harga Properti Residensial terhadap permintaan Kredit Kepemilikan Rumah (KPR)

\section{Tujuan Penelitian}

Berdasarkan permasalahan dalam penelitian, maka tujuan penelitian ini dirumuskan sebagai berikut :

1. Untuk mengetahui pengaruh Pertumbuhan Ekonomi terhadap permintaan Kredit Kepemilikan Rumah (KPR)

2. Untuk mengetahui pengaruh Suku Bunga Kredit terhadap permintaan Kredit Kepemilikan Rumah (KPR)

3. Untuk mengetahui pengaruh Indeks Harga Properti Residensial terhadap permintaan Kredit Kepemilikan Rumah (KPR)

\section{METODE}

\section{Definisi Operasional}

Bagian ini akan membahas tentang pengertian dan jenis variabel dependen, dan variabel independen. Variabel dependen dalam penelitian ini menggunakan Jumlah Permintaan KPR. Sedangkan terdapat variabel independen penelitian ini adalah Pertumbuhan Ekonomi, Suku Bunga Kredit, dan Indeks Harga Properti Residensial. Variabel dependen merupakan variabel terikat dan dipengaruhi oleh variabel lainnya (Ghozali, 2006). Variabel dependen yang digunakan pada penelitian ini adalah jumlah Permintaan KPR. Variabel independen merupakan variabel bebas yang menjelaskan atau mempengaruhi variabel dependen. Variabel independen yang digunakan dalam penelitian ini adalah Pertumbuhan Ekonomi, Suku Bunga Kredit, dan Indeks Harga Properti Residensial.

1. Kredit Pemilikan Rumah (Y) merupakan suatu fasilitas kredit untuk membeli atau memperbaiki rumah yang diberikan oleh lembaga keuangan (perbankan) kepada para nasabahnya (masyarakat). Secara umum kredit kepemilikan adalah KPR (Kredit Pemilikan Rumah) adalah kredit yang digunakan untuk membeli rumah atau untuk memenuhi kebutuhan konsumtif dengan jaminan/agunan berupa rumah dalam Rupiah per tahun.

2. Pertumbuhan Ekonomi $\left(\mathrm{X}_{1}\right)$. Variabel yang digunakan untuk menghitung Pertumbuhan Ekonomi adalah produk domestik bruto berdasarkan harga konstan, Secara matematis, rumus perhitungan pertumbuhan ekonomi adalah sebagai berikut: $\mathrm{G}_{\mathrm{t}}=\left(\mathrm{PDB}_{\mathrm{t}}-\mathrm{PDB}_{\mathrm{t}-1}\right) / \mathrm{PDB}_{\mathrm{t}} \times 100 \%$ 
3. Suku Bunga Kredit $\left(\mathrm{X}_{2}\right)$ adalah besarnya rata-rata bunga yang harus dibayar atas pengambilan kredit dari perbankan yang dinyatakan dalam bentuk persen setiap tahun.

Indeks Harga Properti Residensial $\left(\mathrm{X}_{3}\right)$ adalah data Indeks Harga Properti Residensial (IHPR) adalah salah satu indikator ekonomi yang memberikan informasi mengenai perkembangan properti residensial baik pada triwulan berjalan maupun triwulan yang akan datang. (www.bi.go.id)

\section{Jenis dan Sumber Data}

Jenis dan sumber data penelitian merupakan faktor yang penting yang menjadi pertimbangan yang menentukan metode pengumpulan data. Data yang digunakan dalam penelitian ini adalah data sekunder. Data sekunder merupakan sumber data penelitian yang diperoleh peneliti secara tidak langsung melalui media perantara atau diperoleh dan dicatat oleh pihak lain (Indriantoro dan Supomo, 1999). Dalam penelitian ini data diperoleh dari Bank Indonesia, dan literatur-literatur lain yang membahas mengenai materi penelitian tersebut.

\section{Metode Pengumpulan Data}

Untuk memperoleh data sekunder dapat dilakukan dengan penelitian arsip (achival research) dan studi kepustakaan. Selain itu juga dilakukan melalui beberapa buku bacaan, literatur atau keterangan-keterangan ilmiah untuk memperoleh teori yang melandasi dalam menganalisa data yang diperoleh.

\section{Metode Analisis Data}

Permintaan Kredit Pemilikan Rumah (KPR) pada bank umum di kota Makassar dipengaruhi oleh variabel bebas (independent variable) yang terdiri dari Pendapatan, Suku Bunga Kredit, Uang Muka dan Lokasi rumah. Metode analisis yang akan digunakan untuk menganalisis pemintaan Kredit Pemilikan Rumah (KPR) dengan menggunakan model analisis inferensial, yaitu analisis regresi berganda yang dinyatakan dalam bentuk fungsi sebagai berikut:

$$
\mathrm{Y}=\mathrm{f}(\mathrm{X} 1, \mathrm{X} 2, \mathrm{X} 3)
$$

atau secara eksplisit dapat dinyatakan dalam fungsi Non Linear berikut:

$$
\mathrm{Y}=\beta 0 . \mathrm{X} 1 \beta 1 . \mathrm{X} 2 \beta 2 \mathrm{X} 3 \beta 3+\mu
$$

Untuk mengestimasi koefisien regresi, Feldstein (1988) mengadakan transformasi ke bentuk linear dengan menggunakan logaritma natural (ln) ke dalam model sehingga diperoleh persamaan sebagai berikut :

$$
\ln \mathrm{Y}=\ln \beta 0+\beta 1 \ln \mathrm{X} 1+\beta 2 \ln \mathrm{X} 2+\beta 3 \ln \mathrm{X} 3+\mu \ldots
$$

Dimana :

$\mathrm{Y}=$ Jumlah Permintaan Kredit Pemilikan Rumah

$\beta 0 \quad=$ Konstanta

$\beta 1, \beta 2, \beta 3, \beta 4=$ Parameter yang akan di estimasi

$\mathrm{X} 1=$ Pertumbuhan Ekonomi

$\mathrm{X} 2 \quad=$ Suku Bunga Kredit

X3 = Indeks Harga Properti Residensial

$\mu$

$=$ Error term 


\section{Uji Asumsi Klasik}

\section{Deteksi Normalitas}

Pengujian normalitas adalah pengujian kenormalan distribusi data (Santosa dan Ashari, 2005). Pengujian normalitas dilakukan dengan maksud untuk melihat normal tidaknya data yang dianalisis. Salah satu uji normalitas untuk mengetahui apakah data menyebar normal atau tidak dengan menggunakan Uji Jarque-Bera dengan membuat hipotesis yang digunakan adalah :

Ho : data residual berdistribusi normal

$\mathrm{Ha}$ : data residual tidak berdistribusi normal

Data penelitian dikatakan menyebar normal atau memenuhi uji normalitas apabila variabel residual berada diatas 0.05 . sebaliknya jika nilai variabel residual berada dibawah 0.05 maka data tersebut tidka berdistribusi normal atau tidak memenuhi uji normalitas.

\section{Deteksi Multikolinearitas}

Dikemukakan pertama kali oleh Ragner Frish dalam bukunya "eestatistical Confluence Analysis by Means of Complete Regression Systems ${ }^{\text {eeee }}$. Frish menyatakan bahwa multikololinier adalah adanya lebih dari satu hubungan linier yang sempurna. Uji Multikolinieritas diperlukan untuk mengetahui ada tidaknya variabel independen yang memiliki kemiripan dengan variabel independen lain dalam satu model. Kemiripan antar variabel independen dalam suatu model akan menyebabkan terjadinya korelasi yang sangat kuat antara suatu variabel independen dengan variabel independen yang lain. Uji Multikolinearitas dalam penelitian ini menggunakan uji klien adapun dasar pengambilan keputusan berdasarkan kliens rule of thumb yang menyatakan bahwa multikolinearitas terjadi apabila $\mathrm{R}^{2}$ yang diperoleh dari auxilary regression lebih tinggi dari pada $\mathrm{R}^{2}$ keseluruhan dari meregres keseluruhan variabel X terhadap Y (Ghozali, 2013).

\section{Deteksi Autokorelasi}

Autokorelasi dikenalkan oleh Maurice G. Kendall dan William R. Buckland. Autokorelasi merupakan korelasi antar anggota observasi yang disusun menurut aturan waktu. (Suharyadi, 2003). Autokorelasi umumnya terjadi pada data time series. Hal ini karena observasi-observasi pada data timeserie mengukuti urutan alamiah antarwaktu sehingga observasi-observasi secara berturut-turut mengandung interkorelasi, khususnya jika rentang waktu diantara observasi yang berurutan adalah rentang waktu yang pendek, seperti hari, minggi atau bulan (Gujarati, 2012).

Menguji autokorelasi dalam suatu model bertujuan untuk mengetahui ada tidaknya korelasi antara variabel penganggu (et) pada periode tertentu dengan variabel penganggu periode sebelumnya (et-1). Uji yang digunakan dalam mendeteksi masalah autokorelasi dalam model menggunakan Uji LM test. Uji LM akan menghasilkan Statistik BreucshGodfrey dengan meregres variabel pengganggu/residual. (Ghozali, 2013).

\section{Deteksi Heteroskedastisitas}

Heteroskedastisitas untuk menunjukkan nilai varian antar nilai $\mathrm{Y}$ tidaklah sama atau hetero. Hal demikian sering terjadi pada data yang bersifat cross section, yaitu data yang dihasilkan pada suatu waktu dengan responden yang banyak. Heterokedastisitas menguji terjadinya perbedaan variance residual suatu periode pengamatan ke periode pengamatan yang lain. 
Model regresi yang baik adalah model regresi yang memiliki persamaan variance residual suatu periode pengamatan dengan periode pengamatan yang lain sehingga dapat dikatakan model tersebut homokesdatisitas dan tidak terjadi heterokedastisitas. Model regresi yang baik adalah yang homoskedastik dan tidak terjadi heteroskedastisitas dalam penelitian ini menggunakan uji Glejser. Adapun dasar pengambilan keputusannya adalah jika probabilitas signifikansinya diatas tingkat kepercayaan 5\% maka model regresi memenuhi asumsi heteroskedastisitas atau model regresi terbebas dari penyakit heteroskedastisitas.

\section{Uji Statistik}

\section{Uji Statistik (Uji t)}

Uji ini digunakan untuk mengetahui apakah masing-masing variabel independen secara sendiri-sendiri mempunyai pengaruh secara signifikan terhadap variabel dependen. Dengan kata lain, untuk mengetahui apakah masing-masing variabel independen dapat menjelaskan perubahan yang terjadi pada variabel dependen secara nyata.

Untuk mengkaji pengaruh variabel independen terhadap dependen secara individu dapat dilihat hipotesis berikut: $\mathrm{H} 0: \beta 1=0$ tidak berpengaruh, $\mathrm{H} 1: \beta 1>0$ berpengaruh positif, $\mathrm{H} 1: B 1<0$ berpengaruh negatif. Dimana $B 1$ adalah koefisien variabel independen ke-1 yaitu nilaiparameter hipotesis. Biasanya nilai $\beta$ dianggap nol, artinya tidak ada pengaruh variabel X1 terhadap Y. Bila nilai probabilitas t dibawah 0.05 maka Ho diterima (signifikan) dan jika nilai probabilitas $\mathrm{t}$ diatas Ho diterima (tidak signifikan). Uji $\mathrm{t}$ digunakan untuk membuat keputusan apakah hipotesis terbukti atau tidak, dimana tingkat signifikan yang digunakan yaitu $5 \%$.

\section{Uji Koefisien Determinasi (R-square)}

Koefisien Determinan $\left(\mathrm{R}^{2}\right)$ pada intinya mengukur kebenaran model analisis regresi. Dimana analisisnya adalah apabila nilai $\mathrm{R}^{2}$ mendekati angka 1 , maka variabel independen semakin mendekati hubungan dengan variabel dependen sehingga dapat dikatakan bahwa penggunaan model tersebut dapat dibenarkan. Model yang baik adalah model yang meminimumkan residual berarti variasi variabel independen dapat menerangkan variabel dependennya dengan $\alpha$ sebesar diatas 0,75 (Gujarati, 2003), sehingga diperoleh korelasi yang tinggi antara variabel dependen dan variabel independen. Akan tetapi ada kalanya dalam penggunaan koefisisen determinasi terjadi bias terhadap satu variabel indipenden yang dimasukkan dalam model. Setiap tambahan satu variabel indipenden akan menyebabkan peningkatan $\mathrm{R}^{2}$, tidak peduli apakah variabel tersebut berpengaruh secara siginifikan terhadap variabel dependen (memiliki nilai t yang signifikan).

\section{Uji F (F-test)}

Uji ini digunakan untuk mengetahui pengaruh variabel independen secara signifikan terhadap variabel dependen. Dimana jika nilai probabilitas F diatas 0.05 , maka H0 diterima atau variabel independen secara bersama-sama tidak memiliki pengaruh terhadap variabel dependen (tidak signifikan) dengan kata lain perubahan yang terjadi pada variabel terikat tidak dapat dijelaskan oleh perubahan variabel independen, dan jika nilai probabilitas $\mathrm{F}$ dibawah 0.05 maka variabel independen secra bersama-sama memiliki pengaruh terhadap variabel dependen, dimana tingkat signifikansi yang digunakan yaitu $5 \%$. 


\section{HASIL DAN PEMBAHASAN}

Uji Asumsi Klasik bertujuan untuk mengetahui apakah model regresi yang akan diolah itu baik atau tidak juga digunakan untuk mengevaluasi hasil regresi. Suatu model dikatakan baik apabila bersifat BLUE (Best Linear Unbiased Estimatory), yaitu terhindar dari masalah-masalah multikolinear, heterokedastisitas, auto korelasi maupun uji linearitas. Oleh karena itu dalam penelitian dilakukan uji asumsi klasik agar dapat diketahui apakah terjadi penyimpangan atau tidak, sehingga model yang digunakan penelitian layak untuk digunakan atau tidak.

\section{Deteksi Normalitas}

Pengujian normalitas adalah pengujian kenormalan distribusi data (Santosa dan Ashari, 2005). Pengujian normalitas dilakukan dengan maksud untuk melihat normal tidaknya data yang dianalisis. Salah satu uji normalitas untuk mengetahui apakah data menyebar normal atau tidak dengan menggunakan ketentuan jika f-statistik > f-tabel maka H0 ditolak dan Ha Diterima berarti variabel independen berpengaruh signifikan terhadap variabel dependen secara bersama-sama.

Pada penelitian ini uji normalitas menggunakan uji Houstman Test Jarque-Bera, apabila probabilitas dari hasi uji normalitas dibawah 0,05 maka dapat disimpulkan bahwa distribusi data yang digunakan tidak normal. Sebaliknya jika hasil uji normalitas diatas 0,05 maka dapat disimpulkan distribusi data yang digunakan dalam penelitian berdistribusi Normal.

Tabel 1

\section{Hasil Uji Normalitas}

\begin{tabular}{|l|l|}
\hline Jarque Bera & Probability \\
\hline 3.715845 & 0.155996 \\
\hline
\end{tabular}

Sumber. Hasil Uji Eviews 8

Dari hasil uji normalitas menggunakan metode Jarque Bera dengan menunujukkan angka probabilitas 0.155996 maka dapat disimpulkan bahwa data yang digunakan berdistribusi normal.

\section{Deteksi Multikolinearitas}

Uji Multikolinearitas digunakan untuk melihat hubungan linear antara variabel independen yaitu Pertumbuhan Ekonomi, Suku Bunga Kredit, dan Indeks Harga Property Residential di dalam regresi berganda dalam persamaan. Dalam mendeteksi ada atau tidaknya multikolinearitas penulis menggunakan regresi auxiliary yaitu dengan melihat hubungan secara individual antara satu variabel independen dengan satu variabel independen yang lain. dengan kata lain menunjukkan perbandingan nilai $\mathrm{R}^{2}$ regresi parsial dengan nilai $\mathrm{R}^{2}$ regresi utama. Apabila antar variabel bebas $>$ dari $\mathrm{R}^{2}$ model, maka ada indikasi terdapat Multikolinieritas, demikian pula sebaliknya apabila $\mathrm{R}^{2}$ antar variabel $<\mathrm{R}^{2}$ model, maka tidak ada multikolinieritas.

Tabel 2

Uji Multikolinearitas Auxiliary Regresion

\begin{tabular}{|l|l|l|}
\hline $\mathbf{R}^{\mathbf{2}}$ Regresi Utama & $\mathrm{R}^{\mathbf{2}}$ & 0.979 \\
\hline \multirow{3}{*}{$\mathbf{R}^{\mathbf{2}}$ Regresi Parsial } & $\mathrm{R}_{1}{ }^{2}$ & 0.970 \\
\cline { 2 - 3 } & $\mathrm{R}_{2}{ }^{2}$ & 0.546 \\
\cline { 2 - 3 } & $\mathrm{R}_{3}{ }^{2}$ & 0.967 \\
\hline
\end{tabular}

Sumber : Hasil Uji Eviews 8 
Dalam melihat hubungan menggunakan model auxiliary menggunakan eviews 8 diperoleh R-squared regresi Partial antar ketiga variabel independent lebih kecil dari RSquared regresi utama digunakan untuk uji multikolinearitas yaitu 0.979. Berarti variable Pertumbuhan Ekonomi, Suku Bunga Kredit, Indeks Harga property Residential tidak terdapat masalah multikolinearitas.

\section{Deteksi Autokorelasi}

Autokorelasi adalah adanya hubungan korelasi antara anggota observasi satu dengan observasi lain yang berlainan waktu. Dalam kaitannya dengan asumsi metode OLS, autokorelasi merupakan korelasi antar satu variabel gangguan dengan variabel gangguan yang lain (Widarjono,2013). Pada penelitian ini untuk mendeteksi ada tidaknya masalah autokorelasi yaitu menggunakan metode Correlation LM Test. Uji LM test menghasilkan statistik Breush-godfrey dengan meregres variabel penganggu (residual).

\section{Tabel 3}

Autokorelasi LM test

\begin{tabular}{|c|c|c|c|}
\hline \multicolumn{3}{|c|}{ Breusch-Godfrey Serial Correlation LM Test: } & \\
\hline F-statistic & 2.597652 & Prob. F(2,25) & \\
\hline Obs*R-squared & 5.333757 & Prob. Chi-Square(2) & 0.0695 \\
\hline
\end{tabular}

\section{Sumber : Hasil Uji Eviews 8}

Hasil Uji Autokorelasi menggunakan LM Test diatas menunjukkan bahwa angka Obs*R-squared probabilitas Chi-square sebesar 0.0695, artinya $\mathrm{H} 1$ ditolak dan $\mathrm{H} 0$ diterima sehingga dapat dikatakan data dalam penetian ini tidak terdapat masalah Autokorelasi.

\section{Deteksi Heteroskedastisitas}

Uji heteroskedasitas dilakukan untuk menguji apakah dalam model regresi terjadi ketidaksamaan varian dari residual satu pengamatan dengan pengamatan yang lain. Heteroskedastisitas muncul apabila kesalahan atau residual dari model yang diamati tidak memiliki variasi yang konstan dari variasi satu observasi ke observasi lainnya. Untuk mendeteksi ada tidaknya heteroskedastisitas dalam penelitian ini dilakukan dengan melihat probabilitasyang menyat akan apabila probabilitas lebih kecil dari alpha 0,05 maka menunjukkan adanya heterokedastisitas, dan sebaliknya, apabila probabilitas lebih besar dari alpha 0,05 maka menunjukkan tidak adanya heterokedastisitas.

\section{Tabel Uji 4}

Heteroskedastisitas Glejser

\begin{tabular}{|l|r|l|l|}
\hline \multicolumn{3}{|l|}{ Heteroskedasticity Test: Glejser } & \\
\hline F-statistic & 2.466118 & Prob. F(6,24) & 0.0837 \\
\hline Obs*R-squared & 6.667440 & Prob. Chi-Square(6) & 0.0833 \\
\hline
\end{tabular}

\section{Sumber : Hasil Uji Eviews 8}

Pada penelitian ini Uji Heteroskedastisitas menggunakan uji Glejser, dari hasil uji heteroskedastisitsas diatas dapat lihat nilai Probabilitas signifikan pada 0.05 sehingga dapat disimpulkan bahwa model model dalam penelitian ini terbebas dari penyakit heteroskedastisitas. 


\section{Pengujian Statististik Analisis Regresi Koefisien determinasi $\mathbf{R}^{2}$}

Koefisien determinasi digunkan untuk melihat dan mengukur seberapa besar kemampuan model dalam menenrangkan variasi variabel dpenden. Apabila nilai $\mathrm{R}^{2}$ kurang dari 50\% maka dapat dikatakan kemampuan variabel-variabel independen dalam menjelaskan variasi variabel dependen amat terbatas, sebaliknya apabila nilai $\mathrm{R}^{2}$ lebih dari 50\% maka dapat dikatakan variabel-variabel independen mamapu menjelaskan variasi variabel dependen.

Hasil regresi menunjukkan nilai $\mathrm{R}^{2}$ untuk model penelitian ini yaitu sbesar $97.9 \%$. hal tersebut mengartikan bahwa variabel Pertumbuhan Ekonomi, Suku Bunga Kredit dan Indeks Harga Property Residential mampu menjelaskan sebesar 97.9\% sedang sisianya dijelaskan oleh variabel lain diluar penelitian ini.

\section{Uji Signifikansi Parsial (Uji t)}

Uji T-stat dilakukan untuk mengetahui signifikansi masing-masing variabel bebas dalam mempengaruhi variabel tidak bebas. Dalam uji ini, suatu koefisien disebut signifikan secara statistik jika t-stat berada pada daerah kritis yang dibatasi oleh nilai ttabel sesuai dengan tingkat signifikansi tertentu.

Tabel 5

Uji t Partial

\begin{tabular}{|c|r|r|r|r|}
\hline Variable & Coefficient & Std. Error & t-Statistic & Prob. \\
\hline $\ln \mathrm{X} 1$ & 15.23034 & 5.098316 & 2.987328 & 0.0059 \\
\hline $\ln \mathrm{X} 2$ & -1.057092 & 0.319891 & -3.304542 & 0.0027 \\
\hline $\ln \mathrm{X} 3$ & 6.532414 & 2.399907 & 2.721944 & 0.0112 \\
\hline $\mathrm{C}$ & -33.24615 & 13.73716 & -2.420162 & 0.0225 \\
\hline
\end{tabular}

Sumber : Hasil Uji Eviews 8

Uji T-stat dilakukan untuk mengetahui signifikansi masing-masing variabel bebas dalam mempengaruhi variabel tidak bebas. Dalam uji ini, suatu koefisien disebut signifikan secara statistik jika t-stat berada pada daerah kritis yang dibatasi oleh nilai ttabel sesuai dengan tingkat signifikansi tertentu.

1. Variabel Pertumbuhan Ekonomi

Hipotesisnya adalah :

-Ho = Tidak terdapat pengaruh Pertumbuhan Ekonomi terhadap Kredit Pemilikan Rumah

- $\mathrm{H}_{1}=$ Terdapat pengaruh Pertumbuhan Ekonomi terhadap Kredit Pemilikan Rumah

Dari hasil estimasi dapat dilihat bahwa probabilitas nilai t statistik menunjukkan signifikan pada 0.05 sehingga dapat disimpulkan $\mathrm{H} 0$ ditolak dan h1 diterima. Artinya secara partial Pertumbuhan Ekonomi berpengaruh posistif dan siginifiakan terhadap Kredit Pemilikan Rumah. 
2. Variabel Suku Bunga Kredit

Hipotesisnya adalah :

-Ho = Tidak terdapat pengaruh Suku Bunga Kredit terhadap Kredit Pemilikan Rumah

- $\mathrm{H}_{1}=$ Terdapat pengaruh Suku Bunga Kredit terhadap Kredit Pemilikan Rumah

Dari hasil estimasi dapat dilihat bahwa probabilitas nilai $\mathrm{t}$ statistik menunjukkan signifikan pada 0.05 sehingga dapat disimpulkan $\mathrm{H} 0$ ditolak dan h1 diterima. Artinya secara partial Suku Bunga Kredit berpengaruh negatif dan siginifiakan terhadap Kredit Pemilikan Rumah.

3. Variabel Indeks Harga Property Residential

Hipotesisnya adalah :

-Ho = Tidak terdapat Indeks Harga Property Residential pengaruh terhadap Kredit Pemilikan Rumah

$\cdot \mathrm{H}_{1}=$ Terdapat pengaruh Indeks Harga Property Residential terhadap Kredit Pemilikan Rumah

Dari hasil estimasi dapat dilihat bahwa probabilitas nilai $\mathrm{t}$ statistik menunjukkan signifikan pada 0.05 sehingga dapat disimpulkan $\mathrm{H} 0$ ditolak dan h1 diterima. Artinya secara partial Indeks Harga Property Residential berpengaruh posistif dan siginifiakan terhadap Kredit Pemilikan Rumah.

\section{Uji F Statistik}

Pengujian F-statistik digunakan untuk menguji signifikansi dari semua variabel bebas sebagai suatu kesatuan atau mengukur pengaruh variabel bebas secara bersama-sama.

\section{Tabel 6}

\section{Uji F Statistik}

\begin{tabular}{|l|r|}
\hline F-statistic & 433.6320 \\
\hline Prob(F-statistic) & 0.000000 \\
\hline \multicolumn{2}{|l|}{ Sumber : Hasil Uji Eviews 8}
\end{tabular}

Dari hasil regresi diperoleh nilai probabilitas $F$ statistic 0,0000, dengan menggunakan level of signifikan atau alpha 5\%, maka $\mathrm{F}$ statistic dinyatakan signifikan, karena Probabilitas F statistic lebih kecil dari alpha 5\%. Artinya secara simultan Variabel Pertumbuhan Ekonomi, Suku Bunga Kredit dan Indeks Harga Property Residential Berpengaruh bersama-sama terhadap Kredit Pemilikan Rumah.

\section{Model Persaamaan Regresi}

Permintaan Kredit Pemilikan Rumah (KPR) pada bank umum di kota Makassar dipengaruhi oleh variabel bebas (independent variable) yang terdiri dari Pertumbuhan Ekonomi, Suku Bunga Kredit, dan Indeks Harga Property Residential. Metode analisis yang digunakan untuk menganalisis pemintaan Kredit Pemilikan Rumah (KPR) dengan menggunakan model analisis inferensial, setelah dialkukanolah data menggunakan eviews 8 didapatkan persamaan sebagi berikut: 
Tabel 7

Persamaan Regresi Berganda

\begin{tabular}{|c|c|}
\hline Variable & Coefficient \\
\hline $\ln \mathrm{X} 1$ & 15.23034 \\
\hline $\ln \mathrm{X} 2$ & -1.057092 \\
\hline $\ln \mathrm{X} 3$ & 6.532414 \\
\hline $\mathrm{C}$ & -33.24615 \\
\hline
\end{tabular}

Sumber : Hasil Uji Evies 8

Berdasarkan tabel diatas dapat diketahui model persamaan regresi Dalam regresi dengan menggunakan Ordinary Least Square (OLS), diperoleh nilai koefisien regresi untuk setiap variabel dalam penelitian dengan persamaan sebagai berikut :

$$
Y=-33.24615+15.23034 \ln X 1_{t}-1.057092 \ln X 2_{t}+6.532414 \ln X 3_{t}+\mu
$$

1. Pengaruh Pertumbuhan Ekonomi Terhadap Permintaan Kredit Pemilikan Rumah

Dari hasil regresi dan persamaan diatas menunjukkan Pertumbuhan Ekonomi memiliki pengaruh yang positif dan signifikan terhadap Permintaan Kredit Pemilikan Rumah di Indonesia. Hasil penelitian diatas berhasil membuktikan hipotesis yang menyatakan “ Pertumbuhan Ekonomi berpengaruh positif terhadap Permintaan Kredit Pemilikan Rumah". Asumsi dari persamaan diatas adalah apabila terjadi kenaikan Pertumbuhan Ekonomi sebesar 1\% maka akan menyebabkan kenaikan Permintaan Kredit Pemilikan Rumah sebesar 15,23\%. Artinya apabila Pertumbuhan Ekonomi naik sebesar 1\% maka Permintaan Kredit Pemilikan Rumah juga akan naik 15,23\%, berarti terdapat hubungan searah antara Pertumbuhan Ekonomi dan Permintaan Kredit Pemilikan Rumah.

2. Pengaruh Suku Bunga Kredit Terhadap Permintaan Kredit Pemilikan Rumah

Dari hasil regresi dan persamaan diatas menunjukkan Suku bunga kredit memiliki pengaruh yang negatif dan signifikan terhadap Permintaan Kredit Pemilikan Rumah di Indonesia. Hasil penelitian diatas berhasil membuktikan hipotesis yang menyatakan " Suku Bunga Kredit berpengaruh negatif terhadap Permintaan Kredit Pemilikan Rumah". Asumsi dari persamaan diatas adalah apabila terjadi kenaikan Suku Bunga Kredit sebesar 1\% maka akan menyebabkan Penurunan Permintaan Kredit Pemilikan Rumah sebesar 1,05\%. Artinya apabila Suku Bunga Kredit meningkat sebesar 1\% maka Permintaan Kredit Pemilikan Rumah akan terjadi penurunan sebesar 1,05\%, berarti terdapat hubungan berlawanan antara Suku Bunga Kredit dan Permintaan Kredit Pemilikan Rumah.

3. Pengaruh Indeks Harga Property Residential Terhadap Permintaan Kredit Pemilikan Rumah

Dari hasil regresi dan persamaan diatas menunjukkan Indeks Harga Property Residential memiliki pengaruh yang positif dan signifikan terhadap Permintaan Kredit Pemilikan Rumah di Indonesia. Hasil penelitian diatas berhasil membuktikan hipotesis yang menyatakan "Indeks Harga Property Residential berpengaruh positif terhadap tingkat kemiskinan". 
Asumsi dari persamaan diatas adalah apabila terjadi kenaikan Indeks Harga Property Residential sebesar 1\% maka akan menyebabkan kenaikan Permintaan Kredit Pemilikan Rumah sebesar 6,53\%. Artinya apabila Indeks Harga Property Residential meningkat sebesar 1\% maka Permintaan Kredit Pemilikan Rumah juga akan meningkat 6,53\%, berarti terdapat hubungan searah antara Indeks Harga Property Residential dan Permintaan Kredit Pemilikan Rumah.

\section{Pembahasan}

\section{Pengaruh Pertumbuhan Ekonomi Terhadap Kredit Pemilikan Rumah}

Pertumbuhan ekonomi adalah salah satu indikator ekonomi dalam menilai kemajuan suatu negara. Pertumbuhan ekonomi yang tinggi mencerminkan tingginya Pendapatan Domestik Bruto yang kemudian berpengaruh pada meningkatnya Pertumbuhan Ekonomi. Menurut Soeharjoto (1998), apabila pendapatan masyarakat meningkat, maka porsi pendapatan yang dibelanjakan untuk kebutuhan non-makanan khususnya yang digunakan untuk membeli rumah atau membayar cicilan KPR menjadi lebih besar.

Berdasarkan hasil analisis, pendapat tersebut terbukti dimana pertumbuhan ekonomi berpengaruh positif terhadap permintaan Kredit Pemilikan Rumah. Dengan kata lain, Pertumbuhan ekonomi suatu negara akan mendorong pada pertumbuhan kredit, termasuk Kredit Pemilikan Rumah. Pertumbuhan ekonomi yang tinggi merujuk pada tingginya pendapatan masyarakat dan tingginya daya beli masyarakat yang berujung pada meningkatnya konsumsi masyarakat, termasuk didalamnya pemenuhan kebutuhan akan perumahan. Besarnya pendapatan akan mempermudah bank dalam pemberian pinjaman karena pendapatan merupakan parameter ukuran dalam menilai kapasitas nasabah dalam mengembalikan pinjaman yang diberikan. Penelitian ini senada dengan penelitian Dewi (2016) yang menyimpulkan bahwa pertumbuhan ekonomi berpengaruh terhadap permintaan Kredit Pemilikan Rumah.

\section{Pengaruh Suku Bunga Kredit Terhadap Kredit Pemilikan Rumah}

Suku bunga kredit adalah harga atau biaya dari penggunaan dana yang tersedia untuk dipinjamkan. Suku bunga kredit adalah suku bunga kebijakan yang mencerminkan sikap atau stance kebijakan moneter yang ditetapkan oleh Bank Indonesia dan dimumkan kepada publik. Dengan mempertimbangkan faktor - faktor lain dalam perekonomian, Bank Indonesia akan menaikan suku bunga kredit apabila inflasi ke depan diperkirakan melampaui target.

Berdasarkan hasil analisis suku bunga merupakan salah satu faktor yang mempengaruhi Kredit Pemilikan Rumah. Peningkatan suku bunga kredit akan mengurangi permintaan Kredit Pemilikan Rumah. Hal ini sesuai dengan pendapat Stiglitz dan Greenwald (2003) yang menyatakan semakin tinggi suku bunga kredit yang mencerminkan semakin mahalnya biaya yang akan dikeluarkan oleh nasabah maka akan menurunkan permintaan kredit, dan sebaliknya semakin rendah suku bunga kredit yang mencerminkan semakin murahnya biaya yang akan meningkatkan permintaan kredit. Penelitian ini sejalan dengan Rakhmawati (2011) yang menyimpulkan suku bunga kredit berpengaruh negatif terhadap Kredit Pemilikan Rumah. 
Published Desember 2017

EKONOMIKAWAN : Jurnal Ilmu Ekonomi dan Studi Pembangunan

ISSN : 1693-7600 (Print), ISSN : 2598-0157 (Online), http://jurnal.umsu.ac.id/index.php/ekawan

\section{Pengaruh Indeks Harga Properti Residensial Terhadap Kredit Pemilikan Rumah}

Data Indeks Harga Properti Residensial (IHPR) adalah salah satu indikator ekonomi yang memberikan informasi mengenai perkembangan properti residensial baik pada triwulan berjalan maupun triwulan yang akan datang. Data Indeks Harga Properti Residensial (IHPR) diperoleh dari Survei Harga Properti Residensial (SHPR) yang dilakukan secara triwulanan untuk memperoleh informasi mengenai perkembangan properti residensial, baik pada triwulan bersangkutan maupun perkiraan triwulan berikutnya (www.bi.go.id)

Berdasarkan hasil analisis Indeks Harga Properti Residensial memiliki pengaruh positif terhadap permintaan Kredit Kepemilikan Rumah. Hasil ini berlawanan dengan hipotesis, dimana peningkatan Indeks Harga Properti Residensial tidak menyurutkan permintaan Kredit Pemilikan Rumah. Dengan diberlakukaknnya Peraturan Bank Indonesia No. 18/16/PBI/2016 tentang penyempurnaan ketentuan Rasio Loan to Value untuk kredit properti mampu mendorong pertumbuhan kredit atau pembiayaan di sektor properti, mengingat sektor tersebut memilki efek multiplier yang besar dalam mendorong pertumbuhan ekonomi. Sejak diberlakukannya kebijakan tersebut pertumbuhan permintaan Kredit Pemilikan Rumah mulai meningkat dari 7,5\% yoy di Juni 2015 menjadi 13,2\% yoy di September 2016, meskipun diawal triwulan pertama 2017 terkoreksi menjadi $12,4 \%$.

Hal ini senada dengan penelitian yang dilakukan SMF (2016) yang menjelaskan bahwa Indeks Harga Properti Residensial adalah variabel yang paling signifikan dan positif dalam mempengaruhi outstanding Kredit Pemilikan Rumah. Hal ini disebabkan karena motif sebagian masyarakat dalam membeli rumah tidak lagi untuk memenuhi kebutuhan papan, namun juga motif investasi.

\section{KESIMPULAN}

Dari analisis yang telah dilakukan di bab V, maka dapat diambil kesimpulan sebagai berikut :

1. Variabel Pertumbuhan ekonomi berpengaruh positif dan signifikan terhadap Kredit Pemilikan Rumah. Pertumbuhan ekonomi yang tinggi merujuk pada tingginya pendapatan dan tingginya daya beli masyarakat yang berujung pada meningkatnya konsumsi masyarakat, termasuk didalamnya pemenuhan kebutuhan akan perumahan.

2. Variabel Suku bunga kredit berpengaruh negatif dan signifikan terhadap Kredit Pemilikan Rumah. Hal ini menunjukan bahwa semakin tinggi suku bunga kredit yang mencerminkan semakin mahalnya biaya yang akan dikeluarkan oleh nasabah sehingga permintaan Kredit Pemilikan Rumah akan menurun.

3. Variabel Indeks Harga Properti Residensial berpengaruh positif dan signifikan terhadap Kredit Pemilikan Rumah. Hasil ini berlawanan dengan hipotesis, dimana peningkatan Indeks Harga Properti Residensial tidak menyurutkan permintaan Kredit Pemilikan Rumah. Permintaan Kredit Pemilikan rumah bukan lagi untuk pemenuhan kebutuhan saja melainkan sebagai sarana investasi. 


\section{SARAN}

Setelah memperhatikan beberapa hasil analisis diatas, maka dapat dikemukakan saran sebagai adalah guna mewujudkan pemenuhan kebutuhan perumahan bagi masyarakat perlu adanya kerja sama yang baik dari Pemerintah, Bank Indonesia sebagai bank sentral dan lembaga keuangan perbankan. Melalui kebijakan moneter Bank Indonesia harus mampu mengendalikan tingkat suku bunga yang akan sangat berpengaruh pada permintaan kredit khususnya Kredit Pemilikan Rumah. Hal ini juga harus diimbangi dengan kinerja pemerintah dalam mengendalikan laju inflasi agar pertumbuhan ekonomi secara riil dapat berdampak positif bagi masyarakat. Bank sentral dan bank umum hendaknya mampu menciptakan produk KPR baru yang dapat dijangkau oleh kalangan menengah ke bawah serta kemudahan dalam proses pencairan realisasi KPR.

\section{DAFTAR PUSTAKA}

Ace, Partadiredja. 1985. Pengantar Ekonomika. BPFE. Yogyakarta.

AIREA. 2001. The Appraisal of Real Estate $9^{\text {th }}$ Edition. Chicago: Illinois.

Bandyopadhyay, Arindam and Asish Saha. 2009. Factors Driving Demand and Default Risk in Residential Housing Loans: Indian Evidence. Munich Personal RePEc Archive.

Bhuono, Agung, N.. 2007. Strategi Jitu Memilih Metode Statistik Penelitian dengan SPSS. Andi. Yogyakarta.

Boediono. 1985. Ekonomi Moneter. Edisi ketiga. BPFE, Yogyakarta.

Boediono. 2009. Teori Pertumbuhan Ekonomi. BPFE, Yogyakarta.

Budi, Mulyo. 2009. Jurnal Bisnis dan Ekonomi: Analisis Permintaan Rumah Sederhana di Kota Semarang. Vol. 16, No. 2, Hal. 126-139. Fakultas Ekonomi Universitas Stikubank, Semarang.

Diulio, Eugene A. 1993. Teori Makro Ekonomi. Cetakan keempat. Erlangga, Jakarta.

Eckert, J. K. 1990. Property Appraisal and Assesment Administration. Chicago: The International Assosiciation of Assessing Officers.

Ghozali, I. 2006. Aplikasi Analisis Multivariate dengan SPSS. Badan Penerbit Universitas Diponegoro. Edisi 3. Semarang.

Gujarati, Damodar. 2012. Ekonometrika Dasar. Penerbit Erlangga. Jakarta.

Indriantoro dan Supomo. 1999. Metodologi Penelitian Bisnis untuk Akuntansi dan Manajemen. Edisi Pertama. BPFE Yogyakarta. Yogyakarta.

Karsidi. 2002. Analisis Faktor-Faktor yang Berpengaruh Terhadap Permintaan dan Penawaran Rumah Sederhana di Kota Semarang. Tesis. Program Pascasarjana Universitas Diponegoro, Semarang.

Mankiw, N. Gregory. 2000. Teori Makroekonomi. Edisi Keempat. Terjemahan : Imam Nurmawan. Erlangga, Jakarta. 
Mishkin, Frederic S. 2008. Ekonomi Uang, Perbankan, Pasar keuangan. Edisi 8, Penerbit Salemba Empat. Jakarta.

Muljono, Teguh Pudjo. 1993. Manajemen Perkreditan Bagi Bank Komersil. BPFE. Yogyakarta.

Purwanto, Suharyadi. 2003. Statistika untuk Ekonomi dan Keuangan Modern. Salemba Empat, Jakarta.

Putong, Iskandar. 2002. Pengantar Ekonomi Mikro dan Makro, Ghalia Indonesia, Jakarta.

Ghozali, Imam dan Ratmono, Dwi. 2013. Analisis Multivariat dan Ekonometrika. Semarang

Rahmawati, Diah. 2011. Faktor-Faktor Yang Mempengaruhi Permintaan Kredit Pemilikan Rumah Pada Bank Umum Di Indonesia. Skripsi. Fakultas Ekonomi Universitas, Surakarta.

SMF. 2016. "Elastisitas Outstanding Kredit Pemilikan Rumah dan Apartemen Terhadap Indikator Pasar Perumahan"

Dewi, Puspa Anggraini. 2016. “Analisis Permintaan Kredit Pemilikan Rumah (Studi kasus Bank Tabungan Negara)” 